\title{
Influencing factor analysis on fish farmer's future Cooperative finance demand----based on the Panjin municipality pilot area in China
}

\author{
Yu Yang1, a, Wang Erda', b, Liu Guangdong, ${ }^{1, c}$ \\ 1School of Economics \& Management, Dalian Ocean University, Dalian, 116052, China \\ 2Faculty of Management and Economics, Dalian University of Technology, Dalian, 116023, China \\ ayuyang770727@163.com, bedwang@dlut.edu.cn, clgd@dlou.edu.cn
}

Keywords: Demand analysis, Cooperative finance, Logit model, Chinese farmer

\begin{abstract}
This paper tries to identify those factors which may have potential influence on the fish farmer's cooperative finance demand. In the process, a total of 442 farmer households as well as small-micro farming enterprises were sampled from the villages in Panjin municipality of Liaoning province in China, where the new form of the rural cooperative finance organization (NFRCFO) experiment was under way. A discrete Logit analysis is used for the parameter estimations. The results show that most assumed factors display statistical significance effect on the fish farmer's willingness to take part in the rural cooperative financing organizations but with different level of sensitivity. The cause and effect are fully discussed following by addressing policy issues related to the rural financing cooperative reforms and environmental protection.
\end{abstract}

\section{Introduction}

The demand of rural cooperative finance has been keeping a positive trending momentum in the Chinese rural areas, which has been playing an essential role in stimulating the Chinese rural economic growth ${ }^{[1,2]}$. Previous studies recognized there are many factors which are able to contribute to the fish farmers' interests of participating in the local finance cooperatives, including fish farmer household characteristics, business types, operation scales, fish farmers' risk attitudes, and the financial service quality ${ }^{[3]}$.It's become a social norm for the fish farmers to pursue the money sources from the local financial entities in China, including the rural finance operatives, the mutual fund aid groups, and/or even friends and relatives ${ }^{[4]}$. Research has shown that both the shareholding system and the shareholding cooperative system are well received and accepted financial property right system in rural areas and they become main money sources for the fish farmers to get loans ${ }^{[5]}$. Among others, the fish farmers' social identity and their perceptions over the finance service quality provided by the finance cooperatives are important factors contributing to the famers' attitudes toward the cooperative participation ${ }^{[6,7]}$. It's been recognized that, to some extent, the reliable local finance cooperatives are able to provide remedy for some shortages that present in the formal credit system.

\section{Theoretical hypothesis and research method}

Based on the forgoing analysis, the relationship between the fish farmers' willingness to participate in the NFRCFO and those potentially influential factors can be expressed in the following discrete Logit model (Eq.(1)):

$$
P_{W T P}=f\left(X_{1}, X_{2}, X_{3}, X_{4}\right)
$$

Where $P_{W T P}$ is dependent variable which represents the probability of a fish farmer who chooses to take part in the NFRCFO, and $X_{1}, X_{2}, X_{3}, X_{4}$ are independent variables which represent the four categories of factors, respectively. Eq. (1) can be used in estimating the effect of each specific factor on fish farmer's willingness to taking part in the NFRCFO. A good characteristic of the discrete Logit model is that it can be used to estimate with a discrete binary data for the dependent variable, and yet there is no need for the assumption on the data distribution such as normal distribution requirement. 
Thus, the model is satisfied with our estimation purposes. Now, lets ' 1 ' stand for the fish farmer who is the member of the NFRCFO; and ' 0 ' for being not a NFRCFO member. Software of SPSS16 is utilized to run the regression model (Eq.(2)):

$$
P_{W T P}=\frac{\exp \left(\beta_{0}+\beta_{1} X_{1}+\mathrm{L}+\beta_{i} X_{i}\right)}{1+\exp \left(\beta_{0}+\beta_{1} X_{1}+\mathrm{L}+\beta_{i} X_{i}\right)} \quad(i=1,2,3,4)
$$

where $P_{W T P}$ is dependent variable, expressing the likelihood a fish farmer who has participated in the NFRCFO. $\beta_{0}$ is a constant, $X_{i}(i=1,2,3,4)$ stands for various factors which influence fish farmers ${ }^{\prime}$ decision-making on whether to participate in the cooperative or not, $\beta_{i}$ is regression coefficients to be estimated, i.e., the marginal contribution to the likelihood for a fish farmer to choose in participating in NFRCFO $\left({ }^{P_{W T P}}\right)$.

\section{Data sources and the variable specifications}

Data sources. With the support and accompany of the local government officials, the survey process went through smoothly. The selected framers were gathered at the local township government auditorium where filling out the survey forms was executed after giving an introduction to the survey purposes by the local government officials who are involved. A total of 460 questionnaires were distributed and of which 442 were completed after eliminating 18 invalid questionnaires, which means the ratio of effective questionnaires reaches as high as $96.09 \%$.

Variable specifications. For the three variables to reflect farmer household's conditions of production/operation, except for the family net income to be ranked in the 5 levels, household production scale is measured by its cultivated land size, and the weight of non-farm income is measured by the percentage of non-farm income which accounts for the total family net income. A complete variable specification is presented in Table 1.

Table 1- Variable specifications and their value coding

\begin{tabular}{|c|c|c|}
\hline Variable & Specification and value coding & $\begin{array}{l}\text { Anticipated } \\
\text { direction }\end{array}$ \\
\hline $\begin{array}{l}\text { Willing to participate in the } \\
\text { finance cooperative? } \\
\text { Family characteristics }\end{array}$ & $\mathrm{Yes}=1 ; \mathrm{No}=0$ & \\
\hline Age of family head (Age) & years & + \\
\hline $\begin{array}{l}\text { Education received by the family } \\
\text { head (Edu) }\end{array}$ & $\begin{array}{c}\text { Primary school }=1 ; \text { middle school }=2 ; \text { high } \\
\text { school }=3 ; \text { college }=4 \text { B.S. }=5 ; \text { M.S. or above }=6\end{array}$ & + \\
\hline $\begin{array}{l}\text { Number of labor in the family ( } \\
\text { Labor) } \\
\text { Status of production }\end{array}$ & Person(s) & $+/-$ \\
\hline Production scale (Land) & $\begin{array}{l}\text { Land size: }<=10 \mathrm{Mu}=1 ; \quad 11 \sim 30 \mathrm{Mu}=2 ; 31 \sim \\
50 \mathrm{Mu}=3 ; \quad 51 \sim 100 \mathrm{Mu}=4 ;>=100 \mathrm{Mu}=5\end{array}$ & + \\
\hline Annual family net income (Inc) & $\begin{array}{c}0 \sim ¥ 10,000=1 ; \quad 10,000 \sim 20,000=2 ; \quad 20,000 \sim \\
30,000=3 ; \quad 30,000 \sim 40,000=4 ; \quad 40,000 \sim 50,000=5 \\
;>>=50,000=6\end{array}$ & 5 \\
\hline Portion of non-agr. Income (Spe) & $\begin{array}{c}<=10 \%=1 ; \quad 10 \% \sim 30 \%=2 ; \quad 30 \% \sim 50 \%=3 ; \quad 50 \% \\
\sim 80 \%=4 ;>=80 \%=5\end{array}$ & - \\
\hline \multicolumn{3}{|l|}{$\begin{array}{l}\text { Perception on the finance } \\
\text { cooperatives }\end{array}$} \\
\hline Family head social identity (Ide) & Ordinary $=0 ;$ with a social identity $=1$ & + \\
\hline $\begin{array}{l}\text { Frequency of money borrowed } \\
\text { (Freq) }\end{array}$ & $\begin{array}{l}\text { Never borrowing money }=1 \text {; borrowing money } \\
\text { occasionally }=2 \text {; borrowing money sometimes }=3 \text {; }\end{array}$ & + \\
\hline
\end{tabular}




\begin{tabular}{|c|c|c|}
\hline & $\begin{array}{l}\text { borrowing money very often }=4 \text {; always borrowing } \\
\text { money }=5\end{array}$ & \\
\hline $\begin{array}{l}\text { Importance of the cooperatives } \\
\text { (Imp) }\end{array}$ & $\begin{array}{l}\text { Not important }=1 \text {; less important }=2 ; \text { important }=3 \\
\quad \text {; relative important }=4 \text {; very important }=5 ;\end{array}$ & + \\
\hline \multicolumn{3}{|l|}{$\begin{array}{l}\text { Opportunity cost of money } \\
\text { borrowing (Cred) }\end{array}$} \\
\hline & $\begin{array}{l}\text { Not known any local loan teller }=0 ; \text { known a local } \\
\text { loan teller }=1\end{array}$ & + \\
\hline $\begin{array}{l}\text { Cost from informal money } \\
\text { sources (Cost) }\end{array}$ & w/o $\cos t=0 ;$ with $\cos t=1$ & - \\
\hline Risk preferences (Risk) & Risk averse $=1$; risk neutral $=2$; risk lover $=3$ & - \\
\hline
\end{tabular}

\section{Model Results and Influencing factor analysis}

Model Results. As shown in Table 2, the estimated value for the $\log$ maximum likelihood is 1,365.89 , the likelihood of Chi square statistic is 66.74 , implies that model reaches a 0.01 level of statistical significance. Overall, the model fits the date well.

Table 2- Estimated Logit regression model results

\begin{tabular}{cccccc}
\hline Variable & $\beta$ & Std. error & Wald Statistic & Df. & Sig. \\
\hline Constant & -22.390 & 7.805 & 7.995 & 1 & 0.005 \\
Age & $0.381^{* * *}$ & 0.202 & 8.127 & 1 & 0.005 \\
Edu & $3.749^{* * *}$ & 1.136 & 8.905 & 1 & 0.004 \\
Labor & -0.747 & 0.682 & 1.163 & 1 & 0.252 \\
Land & $0.398^{* * *}$ & 0.161 & 6.585 & 1 & 0.009 \\
Inc & 0.531 & 0.219 & 2.290 & 1 & 0.107 \\
Spe & $-0.146 * * *$ & 0.052 & 6.943 & 1 & 0.007 \\
Ide & $1.101^{*}$ & 0.628 & 3.165 & 1 & 0.093 \\
Freq & $2.790^{* * *}$ & 0.877 & 10.098 & 1 & 0.000 \\
Imp & $6.990^{* * *}$ & 2.603 & 8.013 & 1 & 0.005 \\
Cred & 0.304 & 0.321 & 1.390 & 1 & 0.308 \\
Cost & -0.120 & 0.438 & 0.061 & 1 & 0.191 \\
Risk & $0.151^{*}$ & 0.074 & 0.865 & 1 & 0.087 \\
\hline
\end{tabular}

Influential factor analyses. As indicated in Table 2, the family sources of income generated will gradually change from migrating work to farming and home businesses. When this happens, the farmer will be more interested in participating in the rural cooperative financial organization. Among the three variables used to describe the fish farmer family production situation, both production scale and the weight of the non-fish income reach the 0.01 level of statistical significance, respectively. As the survey data indicates that the fish farmer household with the fishpond size of over $50 \mathrm{Mu}$, about $70 \%$ of them have chosen participating in the NFRCFO.The three variables designed to reflect the fish farmer perception over the NFRCFO all exhibit positive effects on the fish farmers NFRCFO participation, which is consistent with our expectation. But the frequency of money borrowing and fish farmer's perception on the NFRCFO attain the 0.01 level of statistical significance, whereas the variable for the fish farmer family head's social identity reaches the 0.1 level of statistical significance. According to the EXP $(\beta)$, as the frequency of the fish farmer whose money borrowing activity increases by one more higher level, his willingness to participate in the NFRCFO will rise by 14 times. Tere are three variables used to reflect the opportunity cost for farmer who takes part in the rural financing cooperative. Of the three factors chosen to reflect the opportunity costs imposed on the fish farmers as they paticipate in the NFRCFO, the credit channel does not exhibit any significant influence on the fish farmers' willfulness in participating in the NFRCFO. Data analysis reveals that the vast majority of farmers believe they are either risk neutral or risk lover whereas the 
proportion of risk averse to farmers is less than $30 \%$. Furthermore, the risk love farmers are willing to pay a high cost in participating in the cooperative.

\section{Conclusions and policy implications}

First, with regard to the farmer household characteristics, both the farm size and number of labor presented in a farmer family have a negative effect on the farmer's willingness to participate in the rural financing cooperative organization. Second, as to the establishing the new type of financing organization system, at present, it is now under the stage of uneven development. The internal guarantee system of governance structure and property division need to be further improved; related policy propaganda, law and regulations employed in standardizing financing channels need to be improved. Third, in the national level, at present the rural financing reform and environmental protection should be more focused on the aspect of letting market play a critical role in allocating financial resources for the rural economy. Various new types of the rural cooperative financing organizations should be encouraged.

\section{Acknowledgements}

At the point of finishing this paper, we'd like to express my sincere thanks to all those who have lent me hands in the course of my writing this paper, which was supported by Funding from the Project of "Research of sustainable development path of fishery economy in Liaoning province" (No.201738) conducted by Department of Ocean And Fisheries of Liaoning Province.

\section{References}

[1] M. J. Qian, Y. S. Huang, Political institutions, entrenchments, and the sustainability of economic development - A lesson from rural finance[J]. China Economic Review. 2016 (9):152-178.

[2] S. Sindhu, V. Nehra, S. Luthra, Identification and analysis of barriers in implementation of solar energy in Indian rural sector using integrated ISM and fuzzy MICMAC approach[J].Renewable and Sustainable Energy Reviews. 2016(9):70-88.

[3] L. Farrell, T. R. L. Fry, L. Risse, The significance of financial self-efficacy in explaining women's personal finance behaviour[J]. Economic Psychology. 2016 (6):85-99.

[4] J. J. Jin, R. He, H. Z. Gong, X. Xu, C. Y. He, Farmers' Risk Preferences in Rural China: Measurements and Determinants. International Journal of Environmental Research and Public Health, 2017,14(7):713-716

[5] S. Ouma. From financialization to operations of capital: Historicizing and disentangling the finance - farmland-nexus[J]. Geoforum. 2016 (6):82-93.

[6] M. Purdon, Opening the Black Box of Carbon Finance “Additionality” : The Political Economy of Carbon Finance Effectiveness across Tanzania, Uganda, and Moldova[J].World Development, Volume. 2015 (74):462-478.

[7] P. P. Hu, Incentive analysis on farmers' participation in cooperative in the specialized farming cooperative[J].Issues in Agricultural Economy. 2013 (10):73-82 